\title{
Conservation Implications of Dietary Dilution from Debris Ingestion: Sublethal Effects in Post-Hatchling Loggerhead Sea Turtles
}

\author{
SHANNON J. MCCAULEY AND KAREN A. BJORNDAL
}

Abstract: Ingestion of anthropogenic debris by marine species has been documented extensively; fewer studies have attempted to quantify the sublethal effects caused by debris ingestion. One potential sublethal effect is reduced nutrient gains from diets diluted by consumption of debris. Post-hatchling and juvenile loggerhead sea turtles (Caretta caretta) consume substantial quantities of debris. We evaluated the effects of dietary dilution on voluntary intake in post-hatchling loggerheads to assess their ability to compensate for the presence of inert diluents in their diet by increasing dry mass intakes to maintain nutrient gains. Mean daily intakes of dry mass did not increase significantly with dietary dilution, so intakes of energy and nitrogen on a 50\% dilution diet were significantly lower than on a $10 \%$ dilution diet. Therefore, post-hatchling loggerheads have an extremely limited ability to compensate for dietary dilution and would experience sublethal effects from decreased energy and nitrogen gains on dilute diets. Decreased nutrient intakes have serious conservation implications because of possible decreased growth rates, longer developmental periods at sizes most vulnerable to predation, depleted energy reserves, reduced reproductive output, and decreased survivorship.

Implicaciones para la Conservation, Dilución de Dietas por Ingestion de Basura: Efectos Subletales en Crías de la Tortuga Marina Caretta caretta

Resumen: La ingestión de desperdicios de origen antropogénico por especies marinas ha sido documentada extensivamente; pocos estudios ban atentado cuantificar los efectos subletales ocasionados por la ingestion de basura. Un posible efecto subletal es la reducción en la ganancia de nutrientes por dietas diluídas debido a el consumo de basura. Las criers y juveniles de la tortuga marina Caretta caretta consumen cantidades considerables de basura. Los efectos de la dilución dietética por consumo involuntario fueron evaluados en crías para determinar su habilidad para compensar por la presencia de diluyentes inertes en la dieta, mediante un incremento en la captura de materia seca para mantener la ganacia de nutrientes. El consumo promedio diario de materia seca no se incrementó significativamente con una dilución dietética; la captura de energía y nitrógeno en una dieta con un $50 \%$ de dilución fué significativamente más baja que una dieta con un 10\% de dilución. Así pues, las crías de Caretta caretta tienen una habilidad estremadamente limitada para compensar por dilución de dieta y podria experimentar efectos subletales por disminuciones en la ganacia de energia y nitrógeno en dietas diluidas. La disminución en la captura de nutrientes tiene serias implicaciones de conservación debido a una posible disminución en tasas de crecimiento, periódos de desarrollo más largos a tamaños vulnerables a la depredación, agotamiento de reservas de energia, reducción de la reproducción y disminución en la supervivencia.

\section{Introduction}

The prevalence of persistent anthropogenic debris is a major human alteration of marine environments that affects marine biodiversity and ecosystem function and causes significant mortality and sublethal effects in many marine species through either ingestion or entanglement (National Research Council 1995; Coe \& Rogers 1997). 
Ingestion of debris by marine species has been documented extensively; fewer studies have attempted to quantify the lethal and sublethal effects caused by debris ingestion. The extent of sublethal effects may have greater influence than direct mortality on population productivity through reduced growth rates and reproductive output. Nutrient dilution probably has a sublethal effect on many marine species but has received little attention (Ryan 1988). Nutrient dilution occurs when non-nutritive debris displaces nutritious food in the gut, and it can have a significant effect on the nutrient gain in an animal if sufficient gut capacity is appropriated to debris. Decreased nutrient gain decreases productivity in terms of both somatic growth and reproduction.

Food intake is regulated by many factors, but when animals have unlimited access to palatable, nutritionally adequate food, they regulate dietary intake to meet their energetic and nutrient requirements (Weston \& Poppi 1987). Dilution of nutrient concentrations in diets results in compensatory increases in dry-mass intakes in many species (reviewed in McCauley \& Bjorndal 1999) so that digestible energy intakes and body mass gains in growing animals are constant. These increases, however, eventually are constrained by gut capacity (Van Soest 1994), so intake can no longer be increased to compensate for nutrient dilution, and nutrient gain declines.

Juvenile loggerhead sea turtles (Caretta caretta) are good organisms for evaluating the sublethal effects of nutrient dilution. Pelagic loggerheads feed primarily on gelatinous animals with low nutrient concentrations, such as medusae and ctenophores (Bolten \& Balazs 1995; Bjorndal 1997). Animals that feed normally on nutrient-dilute diets may be more vulnerable to further dilution from debris because they are already near the upper limit of their capacity to increase intake in response to nutrient dilution, or because they may have adaptations that allow them to adjust their intake to a greater extent than do those species that feed on more concentrated diets.

In addition, pelagic loggerheads ingest large amounts of marine debris. Small pelagic loggerheads inhabit convergence zones, which form as a result of opposing physical forces and collect material floating on the surface of the ocean, including anthropogenic debris (Carr 1987). Witherington (1994) reported that, of 50 posthatchling loggerheads captured in convergence zones off the coast of Florida, 32\% had ingested plastics and $34 \%$ had ingested tar. In continued studies based on lay-

age samples from 1006 turtles and samples of the surrounding habitat, post-hatchling loggerheads were found to ingest debris at a frequency equal to its availability in the environment (Witherington, in press). In addition, digestive tracts from four of six pelagic-stage loggerheads examined from the Gulf of Mexico contained debris (Plotkin 1996). Digestive tracts from pelagic juvenile loggerheads captured around the Azores contained substantial quantities of anthropogenic debris, sufficient to suggest that nutrient gain in these animals may have been reduced as a result (A. B. Bolten, personal communication). Pelagic loggerheads ingest debris in such high proportions because they feed indiscriminately, they may mistake debris as prey species, or they ingest debris when grazing on the encrusting organisms attached to debris.

We evaluated the effects of dietary dilution on intake in post-hatchling loggerheads to assess their ability to compensate for the presence of inert diluents in their diet by increasing dry-mass intakes to maintain nutrient gains. The extent to which animals have the physiological plasticity to increase intake to maintain constant energy and nutrient intakes determines their ability to meet their energetic demands on a diet that includes 
substantial quantities of debris. Animals that fail to maintain energy and nutrient gains will suffer sublethal effects in lowered growth and/or reproductive output.

\section{Methods}

On 26 August 1995, 80 loggerhead hatchlings (8 from each of 10 nests) were collected in Broward County, Florida. To control for maternal effects, no more than two hatchlings from each clutch were assigned to one of five treatments. Individuals were systematically divided among the four replicates of each treatment to minimize mass differences among replicates and to ensure that no replicate contained more than one member of a clutch. The four individuals of each replicate were housed together and treated throughout the trial as a single experimental unit. Tanks were lighted with a $20-\mathrm{W}$ full-spectrum bulb (VitaLite), and water temperature was $23-25^{\circ} \mathrm{C}$.

Experimental diets were diluted with inert matter, fumed silica (Sigma Chemical), which was evaluated prior to this feeding trial in the freshwater turtle Trachemys scripta. Eight T scripta were fed a diet with dry mass diluted to $50 \%$ with fumed silica. After 4 weeks on this diet, the turtles were sacrificed as part of an undergraduate laboratory exercise. Examination of the gastrointestinal tracts revealed no accumulation of silica along the gut and no tissue damage.

Experimental diets contained gelatin (275 bloom; Fisher Scientific), fishmeal (Sigma Chemical), and a reptile mineral supplement (Reptocal). Dry mass of the five diets were diluted by $0,10,25,40$, and 50\% inert matter. Organic matter, energy, and nitrogen concentrations reflect these percent dilutions (Table 1). The ratio of gelatin to fishmeal was maintained at 6:1. The nondiluent fraction of all diets was assumed to have equivalent digestibility among the diets because the diluent did not create structural barriers (i.e., in the manner of cell walls or lignin) to the digestion of the other dietary components.

Feeding started on 3 September, and turtles acclimated to the diets for 8 days prior to the trial, which ended 4 October. After the trial, turtles were released in a convergence zone off the east coast of Florida.

Turtles were fed ad libitum for 100 minutes each day (0800-0940 hours). Following feeding, all remaining food was collected and dried at $60^{\circ} \mathrm{C}$. Weighed subsamples were taken from each diet daily, soaked in seawater for the 100-minute feeding period, and dried to determine the dry mass of each diet.

Daily dry-mass intake for each replicate was then calculated as

$$
\text { intake }=\left(\mathrm{WM}_{\text {offered }} \mathrm{X}\left(\mathrm{DM}_{\text {sample }} / \mathrm{WM}_{\text {sample }}\right)\right) \mathrm{DM}_{\mathrm{rf}} \text {, }
$$

where $\mathrm{WM}_{\text {Offered }}$ is the wet mass of food offered, $\mathrm{DM}_{\text {sample }}$ is the dry mass of the diet sample, $\mathrm{WM}_{\text {sample }}$ is the wet mass of the diet sample, and $\mathrm{DM}_{\mathrm{rf}}$ is the dry mass of the remaining food. Densities of the five diets were determined volumetrically and did not differ among diets. Therefore, analyses based on diet volume should yield the same results as presented here for diet mass. Diets were analyzed for organic matter, energy, and nitrogen content following standard procedures (McCauley \& Bjorndal 1999).

The effect of treatment on mass-specific mean daily intakes of dry mass, energy, and nitrogen was evaluated with three separate Kruskal-Wallis analyses. Intakes on the $10 \%$ and 50\% dilution diets were compared with Mann-Whitney $U$ tests. One replicate in the $40 \%$ dilution treatment was excluded from analyses because of a hatchling mortality midtrial. 
Intake can increase rapidly during the early development of feeding. To determine if the level of dilution affected the increase in intake, we examined the relationship between diet and mean dry-mass intakes for three 8-day phases of the trial with a repeatedmeasures analysis of variance. More detailed methodology is in McCauley (1997).

\section{Results and Discussion}

Mean daily intakes of dry mass, energy, or nitrogen did not significantly differ among the five experimental diets (Kruskal-Wallis tests; $\mathrm{df}=4, p>0.05$; Table 2). There was, however, a strong trend toward increased dry-mass intake with $10 \%$ diet dilution. Intakes of energy and nitrogen had similar trends to that of dry-mass intake, except that, as a result of dilution of energy and nitrogen composition in the experimental diets, there was a strong trend for intakes of energy and nitrogen to decrease above $10 \%$ dilution. When intakes of $10 \%$ and $50 \%$ dilution diets were compared, dry-mass intake did not increase at 50\% dilution (two-tailed Mann-Whitney $U$ test, $p=0.386$ ), and intakes of energy and nitrogen decreased significantly (two-tailed Mann-Whitney U tests, $\mathrm{p}=0.021$ for both). Hatchlings did not respond to dietary dilution by significantly increasing dry-mass intake to compensate for significant decreases in energy and nitrogen intakes on the 50\% dilution diet compared with the $10 \%$ dilution diet. Therefore, post-hatchling loggerheads have a limited ability to compensate for dietary dilution by increasing intake and will have reduced energy and nitrogen intakes on diluted diets.

Small body size may have had a role in restricting intake by the loggerheads but is unlikely to have been the only factor. Juvenile freshwater turtles (T scripta) that were similar in body mass (28.7 $\pm 4.9 \mathrm{~g})$ but older (1.5 years versus 2 months) than the loggerheads in this study did increase intake in response to dietary dilution (McCauley \& Bjorndal 1999).

The mean and standard deviation of body mass of replicates (each with four hatchlings) in the first and third phases of the trial were $89.3 \pm 5.1 \mathrm{~g}$ and $98.6 \pm 6.5 \mathrm{~g}$, respectively. The average of the two values (94.0 g) was used as the mean body mass of replicates in the second phase. A comparison of the mean mass-specific dry-mass intakes among the three 8-day phases of the trial revealed a significant interaction between phase and diet (repeated-measures general linear model [GLM]; df =4, $F=5.239$,p $<0.001$ ).

Response to dietary dilution appeared to change with development in loggerheads. Over the course of 24 days, mass-specific dry-mass intake had a nonsignificant tendency to increase in all treatments. These increases, however, were nonparallel among treatments (Table 3). In the final 8-day phase of the trial, turtles on more dilute diets showed a greater tendency to increase dry-mass intake, suggesting that loggerheads in the last phase of the trial were developing increased capacity to compensate for nutrient dilution by increasing intake. This trend implies that the difference in stage of development between the juvenile freshwater turtles and the loggerheads may explain their different responses to dietary dilution.

\section{Conservation Implications}

The limited ability of post-hatchling loggerheads to compensate for dietary dilution by increasing intake has serious conservation implications. A large proportion of the posthatchling loggerheads found off the coast of Florida - of ages comparable to those in this study - have ingested either plastics or tar (Witherington 1994, in press). These turtles 
would experience decreased nutrient intakes that could result in decreased ability to reach appropriate offshore current systems, decreased growth rates, longer developmental periods at sizes most vulnerable to predation, depleted energy reserves, and decreased survivorship.

Research is needed to determine whether the ability to compensate for nutrient dilution increases with size or age in loggerheads. If so, larger turtles would be less affected by ingestion of small amounts of debris but would still be vulnerable to nutrient dilution once the limitation of gut capacity was exceeded. Larger pelagic loggerheads $(10-50 \mathrm{~cm}$ straight carapace length) may be close to the limitation of gut capacity because their natural diet is composed of nutrient-dilute organisms: coelenterate medusae, ctenophores, and salps (Bolten \& Balazs 1995; Bjorndal 1997). Dietary dilution in these

larger turtles would be expected to have sublethal effects through decreased growth rate and fecundity (Bjorndal 1997). Because substantial proportions (up to 51\%) of individuals in loggerhead populations ingest anthropogenic debris (Balazs 1985; Plotkin et al. 1993; Bjorndal et al. 1994; Witherington 1994), the sublethal effects of debris ingestion may have broad, population-level effects that would compromise efforts to protect and restore loggerhead populations.

\section{Acknowledgments}

We thank A. Bolten for assistance in developing the ideas and logistics of this study, B. Margolis and L. Fisher of the Broward County Sea Turtle Conservation Program for providing loggerhead hatchlings, and B. Withering-ton for assisting in release of the hatchlings at sea. P. Eliazar, S. Schneider, and D. Wood assisted with feeding trials. We are grateful to A. Bolten, H. Lillywhite, and L. McEdward for constructive comments on the manuscript and to J. Coe for his support. This study was funded by the Marine Entanglement Research Program of the National Marine Fisheries Service through the Florida Cooperative Fish and Wildlife Research Unit (research work order no. 118 to K. Bjorndal and A. Bolten), the International Women's Fishing Association, the Galen C. Moses scholarship awarded by Bowdoin College, and the Archie Carr Center for Sea Turtle Research. The necessary research permit was obtained from the Florida Department of Environmental Protection. All animal care was in full compliance with guidelines of the University of Florida Institutional Animal Care and Use Committee.

\section{Literature Cited}

Balazs, G. H. 1985. Impact of ocean debris on marine turtles: entanglement and ingestion. Pages 387-429 in R. S. Shomura and H. 0. Yoshida, editors. Proceedings of the workshop on the fate and impact of marine debris. Technical memorandum NOAA-TM-NMFSSWFS-54. National Oceanic and Atmospheric Administration, Honolulu.

Bjorndal, K. A. 1997. Foraging ecology and nutrition of sea turtles. Pages 199-231 in P. L. Lutz and J. A. Musick, editors. The biology of sea turtles. CRC Press, Boca Raton, Florida.

Bjorndal, K. A., A. B. Bolten, and C. J. Lagueux. 1994. Ingestion of marine debris by juvenile sea turtles in coastal Florida habitats. Marine Pollution Bulletin 28:154-158.

Bolten, A. B., and G. H. Balazs. 1995. Biology of the early pelagic stage: the "lost year." Pages 575-581 in K. A. Bjorndal, editor. Biology and conservation of sea turtles. Revised edition. Smithsonian Institution Press, Washington, D.C.

Carr, A. 1987. Impact of nondegradable marine debris on the ecology and survival outlook of sea turtles. Marine Pollution Bulletin 18: 352-356.

Coe, J. M., and D. B. Rogers, editors. 1997. Marine debris: sources, impacts, and solutions. 
Springer-Verlag, New York.

McCauley, S. J. 1997. Effects of dietary dilution in chelonians: implications for their ecology and conservation. M.S. thesis. University of Florida, Gainesville. McCauley, S. J., and K. A. Bjorndal. 1999. Response to dietary dilution in an omnivorous freshwater turtle: implications for ontogenetic dietary shifts. Physiological and Biochemical Zoology 72: 101-108.

National Research Council. 1995. Understanding marine biodiversity. National Academy Press, Washington, D.C.

Plotkin, P. T. 1996. Occurrence and diet of juvenile loggerhead sea turtles, Caretta caretta, in the northwestern Gulf of Mexico. Chelonian Conservation and Biology 2:78-80.

Plotkin, P. T., M. K. Wicksten, and A. F. Amos. 1993. Feeding ecology of the loggerhead sea turtle Caretta caretta in the northwestern Gulf of Mexico. Marine Biology 115:1-15.

Ryan, P. G. 1988. Effects of ingested plastic on seabird feeding: evidence from chickens. Marine Pollution Bulletin 19:125-128.

Van Soest, P. J. 1994. Nutritional ecology of the ruminant. 2nd edition. Comstock Publishing, Ithaca, New York.

Weston, R. H., and D. P. Poppi. 1987. Comparative aspects of food intake. Pages 133-161 in J. B. Hacker and J. H. Ternouth, editors. The nutrition of herbivores. Academic Press, Orlando.

Witherington, B. E. 1994. Flotsam, jetsam, post-hatchling loggerheads, and the advecting surface smorgasbord. Pages 166-168 in K. A. Bjorndal, A. B. Bolten, D. A. Johnson, and P. J. Eliazar, compilers. Proceedings of the 14th annual symposium on sea turtle biology and conservation. Technical memorandum NMFS-SEFSC-351. National Oceanic and Atmospheric Administration, Miami, Florida.

Witherington, B. E. In press. Habitats and bad habits of young loggerhead turtles in the open ocean. In L. Sarti, compiler. Proceedings of the 18th international symposium on sea turtle biology and conservation. Technical memorandum. National Oceanic and Atmospheric Administration, Miami, Florida. 
Table 1. Nutritional composition of experimental diets of loggerhead sea turtles.

\begin{tabular}{lccc}
$\begin{array}{l}\text { Dilution } \\
\text { of diet (\%) }\end{array}$ & $\begin{array}{c}\text { Organic matter } \\
\text { (\% dry mass) }\end{array}$ & $\begin{array}{c}\text { Energy } \\
(\mathrm{kJ} / \mathrm{g} \text { dry mass) }\end{array}$ & $\begin{array}{c}\text { Nitrogen } \\
\text { (\% dry mass) }\end{array}$ \\
\hline 0 & 70.5 & 14.7 & 11.5 \\
10 & 64.5 & 13.3 & 10.4 \\
25 & 53.6 & 11.5 & 8.4 \\
40 & 44.0 & 9.1 & 6.5 \\
50 & 36.9 & 6.7 & 5.4 \\
\hline
\end{tabular}

Table 2. Mass-specific daily intakes of dry mass, energy, and nitrogen by loggerhead sea turtles. *

\begin{tabular}{lccc}
$\begin{array}{l}\text { Dilution } \\
\text { of diet (\%) }\end{array}$ & $\begin{array}{c}\text { Dry mass } \\
(\mathrm{g} / \mathrm{kg} \\
\text { body mass })\end{array}$ & $\begin{array}{c}\text { Energy } \\
(\mathrm{kJ} / \mathrm{kg}\end{array}$ & $\begin{array}{c}\text { Nitrogen } \\
(\mathrm{g} / \mathrm{kg}\end{array}$ \\
\hline 0 & $2.0 \pm 0.8$ & $29.9 \pm 12.6$ & $0.23 \pm 0.10$ \\
10 & $3.6 \pm 1.0$ & $48.8 \pm 13.2$ & $0.38 \pm 0.10$ \\
25 & $2.4 \pm 0.8$ & $26.8 \pm 8.4$ & $0.20 \pm 0.06$ \\
40 & $3.1 \pm 0.7$ & $26.5 \pm 6.2$ & $0.20 \pm 0.05$ \\
50 & $3.0 \pm 1.5$ & $19.4 \pm 9.6$ & $0.16 \pm 0.08$
\end{tabular}

*Values are mean and standard deviation. Within columns, means are not significantly different (Kruskal-Wallis tests, $\mathrm{p}>0.05$ ), but means of energy and nitrogen intakes for the $10 \%$ and $50 \%$ dilution diets are significantly different (Mann WhitneyU tests, $\mathrm{p}=0.021$ for both).

Table 3. Mass-specific daily dry-mass intakes in the three, 8-day phases of the feeding trial of loggerhead sea turtles.*

\begin{tabular}{lccc}
$\begin{array}{l}\text { Dilution } \\
\text { of diet }(\%)\end{array}$ & Pbase 1 & Phase 2 & Phase 3 \\
\hline 0 & $1.63 \pm 0.67$ & $2.10 \pm 0.93$ & $2.14 \pm 1.00$ \\
10 & $3.02 \pm 1.08$ & $3.85 \pm 0.94$ & $4.02 \pm 0.94$ \\
25 & $1.48 \pm 0.57$ & $2.70 \pm 0.77$ & $3.52 \pm 0.97$ \\
40 & $2.18 \pm 0.29$ & $2.79 \pm 0.82$ & $4.28 \pm 1.11$ \\
50 & $1.89 \pm 0.98$ & $2.64 \pm 1.26$ & $4.44 \pm 2.22$
\end{tabular}

*The 24-day feeding trial was divided into three, 8-day phases to evaluate changes in intake during the trial. Values are mean and standard deviation. Means are not significantly different within rows (Kruskal-Wallis tests, $\mathrm{p}>$ 0.05 ) or within columns (repeated-measures analysis of variance, $\mathrm{p}>0.05$ ). 